\title{
China's Global Order: a New Paradigm in South to South Relations
}

\author{
Ernani Contipelli, Simona Picciau
}

\begin{abstract}
"To win one hundred victories in one hundred battles is not the acme of skill. To subdue the enemy without fighting is the acme of skill" (Sun Tsu, The Art of War)
\end{abstract}

\section{Abstract}

This article analyses the evolution of Chinese political foreign policy and its strategy in approaching developing and less developed nations. In this context, the relationship between China and Latin America appears to reveal the practice of the Beijing Consensus when considering their interests: China needs natural resources and new markets for its products, and Latin America needs financial aid and loans to develop its infrastructure and provide social programmes. The absence of the US in the region and the rise of political movements denouncing the American imperialism of the Washington Consensus are all factors that contribute to the expansion of Chinese influence. All these considerations allow a discussion concerning the new role of China in developing countries as an expression of a new emerging order in which China is assuming an important role.

\section{KEY WORDS:}

China, Beïing Consensus, United States, Latin America, New Global Order 


\section{Introduction}

China has confirmed itself as one of the most powerful countries in the world, creating its own model of development and promoting a new form of South to South relations. China has passed a period of self-isolation and ideological foreign policy to enter a period where it becomes a central player in the current global system, through a strategy based on pragmatism and economic interests.

China has created its own form of governance based on the idea of the "Chinese socialism market" and seeks new partners to sustain its wide economic growth. Through the concept of the Beijing Consensus, founded on innovation, diversification and self-determination, Chinese foreign policy has been able to turn itself into an alternative and essential partner for developing and less developed countries.

This article analyses the evolution of Chinese political foreign policy and its strategy in approaching developing and less developed nations. In this context, the relations between China and Latin America are considered, to reveal the practice of the Beijing Consensus when considering their interests: China needs natural resources and new markets for its products, while Latin America needs financial aid and loans to develop its infrastructure and provide social programmes. The absence of the influence of the US in the region and the rise of political movements denouncing the American imperialism of the Washington Consensus are factors that contribute to the expansion of Chinese influence in Latin America. The role of China in developing countries as a new South to South relationship is thus to be discussed.

\section{Rise of the Asiatic Dragon}

The role of China on the global scene is becoming increasingly important in each corner of the world. In less than three decades, China has been 
transformed from an agrarian country into the world's second largest economy, becoming one of the most relevant players in the world economic system. China has been able to create a powerful network of South to South cooperation based on trade investments, manufacturing and commodity markets.

China has emerged since the 1980s as a key partner for developed countries and emerging powers due to the economic reforms promoted by Deng Xiaoping, the leader of the country after Mao Zedong's death. Partnerships situated not only in Asia but also in Africa and Latin America have brought China a host of new opportunities.

Chinese economic reforms have followed a different path from those of other countries that liberalized their markets in the 1980s and 1990s in accordance with the IMF and World Bank. These organisations suggested reform policies based on privatisation, deregulation, unilateral trade and conditional investments. China promoted its process of economic reforms differently: lowering barriers, opening its markets and giving business opportunities to private agents, under state control and with the direct involvement of the Communist Chinese Party (CCP) in the economy.

Notoriously, the Chinese government controls the economy by planning and identifying priorities in the selection of sectors for investment and infrastructure, the creation of human capital, research and strategic fields. This reflects the strong influence of the CCP in the development of the country. The government wanted to create a free area for foreign investment by establishing special economic zones. This has become the engine of the Chinese economy as an important place for technology and import practices on the mainland. In order to restore Hong Kong to the People's Republic of China (PRC) and benefit from its already developed economy, China established a constitutional principle that was also valid for Macau: One Country, Two Systems. According to this principle these two territories could maintain their political system and capitalist economy while China maintained its own "socialist market system".

According to Chinese values the notion of the state is completely different from that of Western values. The state is considered the representative of Chinese civilization, playing partly a spiritual role for society that gives it 
authority and legitimacy without challenging power (Jacques 2009). The relationship between society and the CCP, for example, has a specific dynamic with an implicit agreement wherein people renounce political liberties in exchange for the right to enrich themselves, "To get rich is glorious!" said Deng Xiaoping.

The Chinese consider the state an intimate community, as the patriarch of the family. In Western countries, state power is repeatedly challenged, and society almost always perceives this figure as an intruder. This sort of view explains the participation of the Chinese state in the economy, controlling and intervening in the private sector to confirm its legitimacy and authority, as well as the particular path of its political system.

To reach its actual level of economic development, China passed through a stage of isolation following the Maoist project of development, with a foreign policy based exclusively on ideological motivation in order to spread its political model to the revolutionary movements of the "Third World countries". The foreign policy principles formulated in that time, around the 1950s continue to influence China's behaviour towards lessdeveloped-countries today. This foreign policy includes: 1) mutual respect for territorial integrity, 2) non-aggression, 3) mutual non-interference in the internal affairs of states, 4) equality and mutual benefit, and 5) peaceful coexistence.

During the 1980s and 1990s, China experimented with the beginning of its political and economic transformation, starting with the policy of four modernizations: agriculture, science and technology, industry and defence. These policies were idealised by Zhou Enlai and launched after his death by Deng Xiaoping who introduced policies oriented to attracting foreign direct investments and stimulating the economic development of the country. This would also lead to a new phase of relations between China and southern nations in economic and pragmatic interests, especially in the supply of natural energy resources to support its growth.

International admiration for the spectacular Chinese development was interrupted by the Tiananmen Square protest at the end of the 1980s. The government repressed students who were asking for a fifth modernization, democracy and greater political liberty, taking advantage of the 
visit of the Russian leader Mikhail Gorbachev and the presence of the international media. When Western countries opted for international isolation and embargo, China began intensifying its relationships with developing countries.

The economic and financial crisis that took place in 2008 deeply affected the USA and Europe and allowed China to enhance its relationship with developing countries, especially Africa and Latin America, in order to stimulate the domestic market and diversify exports. These countries represent an alternative to the traditional powers (United States, Europe and Japan), and a model of economic development. In other words, China wanted to establish a new path for relationships with these countries, based on economic and pragmatic interests rather than ideological or geopolitical factors.

Currently, one of the channels that China is using to act globally and also regionally is through a group of countries formed by Brazil, Russia, India, China and South Africa (BRICS), which are considered the future dominant nations of the world economy'. BRICS were initially created as a forum to discuss common interests and homogeneous political strategies in traditional international organisations through annual summits between its leaders. BRICS has been converted to an "institutional agency" with the launch of the New Development Bank and the Contingency Reserve Agreement to provide financial aid to developing countries. Through this channel, China wants to demonstrate its engagement and support for multilateral cooperation on one hand, and on the other hand to move away its image as an imperialist and a dominant country, especially in East Asia.

\section{Dragon's Profile: Beijing's Consensus}

As opposed to Latin America and Africa, which followed the recommendations of financial institutions such as the IMF and World Bank, China chose its own path to increasing its social and economic development, centring its efforts on the "open door policy", creating innovation and increasing state control with a set of principles which

According to the report of investment bank Goldman Sachs "Dreaming with BRICs: The Path to 2050" of 2003, the economies of Brazil, Russia, India and China could together become larger than those of the G6 (Britain, the United States, Germany, Japan, Italy and France) in less than 40 years. 
founded the "Chinese socialist market economy". In Western perceptions, this political formula seems contradictory in itself, but for the Chinese it is not, as Deng Xiaoping stated in 1981: "I think there are more than 100 kinds of socialism in the world, there is no restriction. China will build socialism with Chinese characteristics".

The $16^{\text {th }}$ Congress Party, which took place in 2002, ratified the social political theory of the three representatives as created by former leader Jiang Zemin. According to this theory the CCP should represent advanced forces of social production, advanced culture and the interests of the overwhelming majority. With this political arrangement, the CCP wanted to open itself to the productive forces of the country, managers and businessmen, in order to consolidate its hegemony in society, revealing the pragmatic approach of Chinese socialism and the will to establish its own path of thinking even if it didn't match Western conceptions.

Even today the current leader, Xi Jinping, explains the Chinese way of government using traditional metaphor: "You know if the shoe fits only after you put it on yourself" (Lee 2015) meaning that each nation must look for the political model that best fits its social and cultural expectations of development.

This specific form of governance has shaped the political and economic "Dragon's Profile" creating a new form of "socialism" or "capitalism", depending on the perspective taken. According to its leaders, Chinese society is based on certain principles such as reciprocity and harmony, repurposed in foreign policy strategy towards less developed countries. In particular, as stated by Hu Jintao, China foreign policy aims to "1) strengthen strategic common ground and enhance mutual political trust; 2) take practical and creative steps to tap potential economic cooperation, and 3) attach importance to cultural exchanges to deepen mutual understanding" (Shixue 2006). This demonstrates that the country wants to enhance its image on the global stage and present itself as a good partner.

In 2004 Joshua Ramo introduced the concept of the Beijing Consensus in opposition to the Washington Consensus, to express China's own model of development based on three main characteristics: a) innovation: 
"constant tinkering and constant change, and a recognition that different strategies are appropriate for different situations" (Leonard 2006); b) pursuit of dynamic goals: "rejection of per capita GDP as the be-all and end all" balancing with other focuses such as quality of life and individual equity; and c) self-determination: "valuing independence and self-determination and refusing to let other powers impose their will (...) Countries can plan their own development without having to accept the unfavourable terms of the Washington Consensus" (Gresh 2008).

The "recommendations" of the Western capitalist system were followed by governments in Latin America, Asia and Africa, especially during the 1990s. These recommendations were based on the neoliberal ideology expressed in the concept of the Washington Consensus. The package of policies ofthe Washington Consensus includes free trade agreements, fiscal disciplines and the privatisation of state-owned companies, and clearly demonstrates a unilateral agenda oriented only by the economic and political interests of the North imposed on the South².

Developing nations pursued features of the Beijing Consensus to create their own path and space in the world economic system, resisting the dominant economic policy dictated by the Western international financial institutions such as the World Bank and IMF. In other words, Beijing's Consensus was to be a lesson to enable developing nations to establish their own path of development according to their challenges: "China is writing its own book now. The book represents a fusion of Chinese thinking with lessons learned from the failure of globalization culture in other places. The rest of the world has begun to study this book" (Ramo 2004).

In this context, the success of the Beijing Consensus in its rhetoric of reciprocity and harmony, as supporting the growth of the Chinese economy, convinced Latin American and African governments to follow China's approach. The financial crisis that affected the USA and Europe from 2008 was the decisive factor that allowed a new peripheral network of economic relations from South to South, establishing China as the centre.

2 According to Willianson (2004), the Washington Consensus recommendations are based on: fiscal discipline, restructuring public/social expenditure priorities, tax reform, liberalising interest rates, competitive exchange rates, trade liberalisation, liberalisation of inward foreign investments, privatisation, deregulation and property rights. These policies show the neoliberal orientation of the Washington Consensus and its main preoccupation for the growth of the GDP and openness of national markets. It has been interpreted as a new form of imperialism founded on the unilateral interests of Western hegemonic nations taking advantage of the south (A Short History of the Washington Consensus). 
China presented itself as a new pole of opportunities and advantages for developing and less developed nations in South America and Africa. Both continents can offer their commodities to sustain the increasing economy of the Asiatic Dragon and gain unconditional financial aid in exchange. The aid and loans support their social policies and infrastructure programmes. The dynamics of these relationships reveals the real content of the Beijing Consensus and the pragmatic interest that China has in these countries. One example of this formula of cooperation is given by Niall Ferguson who reported the confirmation of a Chinese leader concerning China's foreign policy strategy in Africa: "we will build up roads, and certain facilities for you, but you make sure that we will have access to the commodities and primary resources. As to your domestic politics and human rights you do whatever that you like" (Ferguson 2010).

\section{International Cooperation under the Wings of China}

China is very quickly imposing itself as a source of finance for southern nations building critical infrastructure which will reduce obstacles to development. These infrastructure projects in Latin America and Africa are closely related to China's economic interests and focus on strategic sectors such as energy, mining, transport and telecommunications. This infrastructure is considered necessary to increase China's trade relationships and influence in these regions.

Possible evidence can be seen in the recent Chinese investment strategy in Africa: "...roads and bridges in Democratic Republic of Congo (DRC), railways in Angola and power stations in Zambia which are often planned around oil and mineral resources. China is constructing high-voltage power transmission lines to interconnect countries in Southern Africa. In the rail sector China's largest deals include the construction of mass transit systems as in Nigeria, and the construction of new lines linked to mining developments in Gabon and Mauritania" (Schiere, Rugamba 2011). When building these infrastructure projects China uses its own labour force which interrupts the generation of local employment. China also tries to obtain privileges in licenses and regulations to exploit the natural resources of these countries. 
This particular Chinese approach demonstrates the real content of the Beijing's Consensus. The pragmatism represents the backbone of the Chinese foreign policy model. As the former president Deng Xiaoping said: "It doesn't matter whether the cat is black or white, as long as it catches mice".

From the perspective of its rhetoric, China continues to diffuse values of reciprocity and harmony. During the 6th BRICS Summit, held in Fortaleza (Brazil) on 16th July 2014, Xi Jinping claimed that everyone should push together for a new world order that is more fair and rational. This new order should be able to guarantee the rights of the peoples to determine their own social system and their way to development. The need to strengthen global governance and demand greater attention to alternative international communities such as BRICS and the balance between the existing International Organisations and new communities was also noted.

To empirically analyse these considerations, we will take an example of the relationship between China and the Latin American countries. This example allows us to understand the pragmatic form of governance, especially with respect to its bilateral relationship with the USA.

\section{China plays in the "backyard" of the US}

The Chinese presence in South America was almost absent until the 1980s, but since the Second World War and during the period of the Cold War the relationship between China and Latin America was characterized by a strong pragmatism. One example is the strengthening of the relationship between China and the dictatorship of Pinochet despite the international isolation of Chile in these years. It is important to note that the socialist Chilean government of Salvador Allende had been the first Latin American country to recognise the PRC, in 1970. China was also able to sign trade agreements with Argentina during the period of the dictatorship between 1976 and 1983. In the 1990s its presence on the continent slowly increased until it reached a high level of influence under the leadership of Hu Jintao. 
In 2014 the current Chinese leader, Xi Jinping, was in South America twice for official visits, demonstrating the importance of this region for Chinese diplomacy not only through the multilateral channel of BRICS but also through bilateral ties such as the launch of the China-CELAC forum (Community of Latin American and Caribbean States) in Beijing in January 2015. "China will make efforts so that both sides can reap early harvests from the forum and build a new model of South-South cooperation"; the speech of the Chinese foreign Minister Wang Yi during the forum highlights Beijing's growing interest in the "backyard" of the United States.

It is important to note that the relationship between the United States and Latin America has become "colder" in recent years and China seems to be an alternative partner for the countries of the region. Very recently there have been signs of a possible new US approach to the region, as suggested by the participation of Barack Obama in the Summit of the Americas held in Panama (April 2015), which was the occasion of Obama's historical meeting with Raul Castro, President of Cuba, after the bilateral relationship has been at odds for more than 50 years.

Between 1945 and 1990, the Cold War transformed Latin America to a space of political interest for Washington, a silent field of battle in which to contain possible incursions of the Soviet Union and the spread of socialism in the region. Political movements oriented by social ideas were reasons given for US intervention in Latin America.

The 1990s was the end of political conflict led by leftists and Washington's approach towards Latin America changed from a political and military focus to an economic strategy with a pragmatic agenda of trade and investment based on the Washington Consensus. This political behaviour can be seen in some of the US's strategic projects, such as the Enterprise for the Americas Initiative (EAI) that aimed to establish a free trade area over Latin America or the programme of debt relief and loans (1990). The North American Free Trade Agreement (NAFTA) signed between the USA, Canada and Mexico was to be an incentive for other Latin American countries like Mexico to join the trade initiative, however, the new political movement in Latin America, led by a leftist ideology representing nationalism, populism and criticism of US policy, started to develop in 2000 and contributed to temporally stopping the "American Free Trade Zone 
Dream". The ideological and political Yankee influence continued to exist strongly in Latin America, especially in the Pacific Alliance countries (Mexico, Chile, Colombia and Peru).

Taking advantage of the distance between Latin America and the US, and the absence of strong external trade partners for the region, China started to increase its presence, generating diversity in terms of foreign relations for Latin America.

As a result of the beginning of the terrorism war launched by George Bush after the 9/11 attacks, the disastrous wars in Afghanistan and Iraq and the "Pivot to Asia" strategy of Obama's Administration, Washington has appeared further and further from Latin America. In this context, the "Pivot to Asia" strategy is an important element in the bilateral relationship of China and the US, because the new American policy in Asia has been idealised in order to contain the military and economic spread of China's influence in Southeast Asia. The statement of the former Secretary of State, Hilary Clinton, is crucial to understanding the relevance of Asia for the US: "The future of politics will be decided in Asia, not Afghanistan and Iraq, and the United States will be right at the center of the action" (Clinton 2011).

Chinese expansion in Latin America was not considered a challenge to US in its backyard. The interdependence of the two first world economic powers was a reason for China to sustain its pragmatic foreign policy of "no intervention" and "only doing business" without affronting the political influence of US in the region.

The neoliberal agenda promoted by the Washington Consensus hasn't been able to attract the entire Latin America region. For the moment, China's approach is attracting most Latin America countries, especially those in which the populist governments have had remarkable success. Countries such as Bolivia, Venezuela and Ecuador are all strengthening their cooperation with China and frequently accuse the USA of imposing an imperialist policy in the region. As stated by the Vice President of Venezuela, Jorge Arreaza: "China has great potential, and it is not imperialist. It is a great potential that wants for all of us respectable and dignify living standards" (Fisher Hoffman 2015). 


\section{Dragon catches the Latin American Mice}

Chinese interests in Latin America are based on a clear strategy. These countries supply China with natural resources such as oil (Venezuela), meat (Argentina), soybeans (Brazil and Argentina), and copper (Chile and Peru) in exchange for loans with low interest rates which could be considered an instrument of diplomacy and a source of profit ${ }^{3}$. This model of cooperation with developing countries and the internationalization of Chinese investments and lending were first put in place by the former Chinese President Jiang Zemin (1989-2002). South American leaders, conscious of this reality, are developing a foreign policy characterised by strategically flirting with China in order to attract more investment. The Vice President of Argentina, Amado Boudou, clearly confirmed: "Relations between China and Argentina will continue to grow for the benefit for our people (...) it is not a simple buyer or trade partner but a strategic partner to work together and have an egalitarian world" (Latin Post 2014), revealing the tendency of South American governments to use populists statements to sustain the new South to South development cooperation, and their necessity to be financially supported by China.

The increase in trade relations between China and Latin America originated with the "commodity boom" between 2003 and 2008, when the internal Chinese capacity to produce raw materials (oil, minerals, foods) began to be insufficient to satisfy its wide economic development. This generated the development of exports from Latin American countries in order to supply Chinese demand.

China has recently signed a trade agreement, for example, with Argentina, called "Convenio Marco de Cooperación en Materia Económica y de Inversiones" which will help to build infrastructure projects in the country. In particular the construction of two hydroelectric dams is planned in Patagonia with loans of US\$ 4.7 billion and US\$2.1 billion, which will be used to make a railroad connecting Argentina's agricultural plants to its ports, for more efficient transport of grains, as China is the largest buyer of Argentinean soybeans.

3 In some cases, these loans are paid directly with commodities. China has already granted US $\$ 50$ billion of credits to 
The most recent visit to Latin America of Xi Jinping (in particular, Brazil, Argentina, Venezuela and Cuba) was the biggest visit of a top Chinese leader in the region since the tour of $\mathrm{Hu}$ Jintao in 2004, accompanied by the Vice President Zeng Qinhong, and represented an important stage in the relationship between China and Latin America because it focused mainly on the signature of trade agreements and the investment cooperation in different sectors. During these ten years, China has been able to enhance its position as a strong partner for Latin American countries and Xi Jinping's trip has been considered a milestone in the development of the relationship between the Asiatic Dragon and the region. Xi Jinping visited Brazil, its first trading partner of the region, to discuss their cooperation and the construction of a high-speed railroad connecting Brazil to Peru, and the Atlantic and Pacific Coasts.

Another emblematic and ambitious engineering project is the construction of the Nicaragua Canal, which will also link the Atlantic and Pacific Oceans, promoted by a private company in Hong Kong (HKND). The group received the concession to build and explore the channel from the Nicaraguan government, headed by Sandinista Daniel Ortega, but it has been criticized by civil society and countries like Costa Rica for its environmental impact. This project would be the greatest engineering construction in history, and it appears to be competition for the US dominance of the shipping route since the building of the Panama Canal. Even if Beijing declares itself not involved in the project, it is obvious that the realisation of this infrastructure work means the reinforcement of China's growing influence in the region and control of the trade route that could weaken the US's historical hegemony.

These examples demonstrate how China is engaged in the development of Latin American infrastructure in order to benefit its economic and political interests, using its pragmatic approach.

China also launched the China-CELAC forum (Community of Latin American and Caribbean States) in Beijing on January 2015. "China will make efforts so that both sides can reap early harvests from the forum and build a new model of South-South cooperation", read the speech of the Chinese Foreign Minister, Wang Yi, during the forum, which highlights Beijing's growing interest in the backyards of the United States. Xi Jinping 
opened the forum by announcing an amount of investment worth US\$ 250 billion in Latin America over the next decade. China also promised an increase of US $\$ 500$ billion in bilateral trade, nearly double the total amount of 2013 (U\$261 billion) which would consolidate the position of China as the second-largest trading partner of Latin America (Tiezzi 2015).

Each year the importance of the Chinese economic presence grows considerably in Latin America countries. Since 2005, China has provided US $\$ 119$ billion in loan commitments to the region, that in 2010 represented more than those of the World Bank, Inter-American Development Bank, and US Export-Import combined. In 2014, for instance, Chinese banks loaned more than US $\$ 22$ billion to Latin America. Usually, Chinese banks (mainly the China Development Bank and China Ex-Im Bank which were both created in order to support the government's policy) have a distinct target of countries to which to provide economic support such as Argentina, Ecuador and Venezuela which have difficulties obtaining loans from international financial institutions.

The following table presents a general view of Chinese loans in Latin America, as updated in 2014 (The Dialogue):

\begin{tabular}{|l|l|l|}
\hline COUNTRY & NUMBER OF LOANS & AMOUNT \\
\hline VENEZUELA & 16 & $\$ 56.3 \mathrm{~B}$ \\
\hline BRAZIL & 10 & $\$ 22 \mathrm{~B}$ \\
\hline ARGENTINA & 10 & $\$ 19 \mathrm{~B}$ \\
\hline ECUADOR & 12 & $\$ 10.8 \mathrm{~B}$ \\
\hline BAHAMAS & 03 & $\$ 2.9 \mathrm{~B}$ \\
\hline MEXICO & 03 & $\$ 2.4 \mathrm{~B}$ \\
\hline PERU & 04 & $\$ 2.3 \mathrm{~B}$ \\
\hline JAMAICA & 08 & $\$ 1.4 \mathrm{~B}$ \\
\hline BOLIVIA & 03 & $\$ 611 \mathrm{M}$ \\
\hline COSTA RICA & 02 & $\$ 401 \mathrm{M}$ \\
\hline HONDURAS & 01 & $\$ 298 \mathrm{M}$ \\
\hline CHILE & 01 & $\$ 150 \mathrm{M}$ \\
\hline GUYANA & 01 & $\$ 130 \mathrm{M}$ \\
\hline COLOMBIA & 01 & $\$ 75 \mathrm{M}$ \\
\hline URUGUAY & 01 & $\$ 10 \mathrm{M}$ \\
\hline
\end{tabular}


This form of cooperation is seen by some experts as a danger for Latin American economies because of their increasing dependence on the exportation of natural resources to China and the privilege of shortterm gains over of long-term uncertainty. In other words, this model of economic relations with China does not encourage the development of the industry of the region, increasing, on the contrary, its dependence on the exportation of its natural resources.

China represents a competitor for Latin American countries - for example, the competition in manufactured goods between China and Mexico for the US market. The manufacturing industry represents three quarters of its exports and since the global expansion of Chinese manufactured products has increased constantly, Mexico has lost competitiveness, particularly in the United States market, vital for the Mexican economy. Another interesting example are the consequences of the already noted agreement between China and Argentina, regarding Brazil, according to which, China will be allowed to produce manufactured goods in Argentina that will reduce the competitive force of the Brazilian industry in the same sectors (Passos 2015). In 2011, nine of the twelve members of the Latin America Integration Association (ALADI ) ${ }^{4}$ registered a trade deficit with China (Manriquez, Alvarez 2014). The trade relationship between China and the region suffers from a lack of reciprocity. Latin America does not, in fact, figure as one of the main trade partners of China.

China is developing its influence in Latin America not only at a bilateral level but also through the multilateral channel of BRICS, confirming itself as the incontestable leader of the group. It has recently played a central role in the establishment of the New Development Bank (NDB), created in order to mobilise resources to finance infrastructure projects in emerging and developing nations 5 . Based in Shanghai, the NDB will have an initial capital of U $\$ 50$ billion funded by the BRICS members. Another important financial initiative is the Contingency Reserve Arrangement (CRA) to provide liquidity to countries that have difficulties in their balance of

4 Argentina, Bolivia, Brazil, Chile, Colombia, Cuba, Ecuador, Mexico, Paraguay, Panama, Peru, Uruguay, Venezuela.

5 The first article of the Agreement of the Development Bank asserts this concept: "The Bank shall mobilize resources for infrastructure and sustainable development projects in BRICS and other emerging economies and developing countries, complementing the existing efforts of multilateral and regional financial institutions for global growth and development". 
payment and head off future economic crises ${ }^{6}$. In the case of the CRA, China is expected to participate with the biggest contribution, US $\$ 41$ billion, followed by Brazil, India and Russia with US\$18 billion, and US $\$ 5$ billion from South Africa, demonstrating China's substantial economic power compared to the other BRICS members.

Actually, it is too early to predict the benefits of the actions of the NDP and the CRA for Latin America and how the relationship between the region, China and the other BRICS members will develop. For the moment, most of the Latin American leaders see these financial institutions as an opportunity for national development and the demand for modernisation by building a system of national infrastructure, making their ties with China stronger.

Despite its engagement at a multilateral level, and a sort of solidarity between BRICS members, the pragmatic Chinese approach and the prevalence of its national interest have been demonstrated on many occasions, such as the competition with Brazilian industry, confirming their approach in a globalized economy: we are together but each one of us is free.

China has a clear foreign policy strategy based on the diversification of its partners through multiple activities, according to what they can offer its development. Its current economic force gives China a predominant position among its partners, especially the peripheral regions with economies that depend on their natural resources.

\section{Conclusion}

The Chinese form of development is based on a strategy of diversification through the establishment of trade relations with multiple partners in different regions in order to expand economic influence.

6 The Contingence Reserve Agreement "is a framework for the provision of support trough liquidity and precautionary instruments in response to actual or potential short-term balance of payments pressures" (Agreement of the 
The trade relationship between China and Latin America has some particularities. Chinese expansion over a zone historically submissive to US influence has been facilitated at least by three factors: the interest of Washington's foreign policy in other regions such as the Middle East and Asia, its unsuccessful strategy to promote Free Trade Agreements and the insurgence of leftist governments which began to spread anti-American ideology.

Chinese foreign policy in Latin America follows a clear agenda: economic interests based on the trade of commodities, supply of raw materials and exploration of new markets for its manufactured products which is compatible with the ideas established in the Beijing Consensus of innovation, diversification and self-determination, which is generating a new model of cooperation from South to South.

Currently, Latin American governments find it convenient to join the Chinese model, because of their need to develop their infrastructure. The Chinese principle of "no intervention" in domestic affairs appears to be of more interest to these governments than the traditional model of political interference of Western powers. China is not concerned about the national issues of its trading partners, but "only doing business" which reflects the pragmatic Chinese way.

China has been able to create its own model of development according to its challenges and demands. It is not a question of evaluating whether this model is good or bad, fair or not, but only to demonstrate that it is important for Latin American countries to rethink their own social and economical development systems on the basis of their needs and society's expectations in order to find their role in the new global order. 


\section{B Bibliography}

China and Latin America: Argentina and China Sign Trade Deals. The Latin Post, New York, USA, July 19, 2014. Available at:www.latinpost.com.

Fischer Hoffman, C., 2015. China commits $\$ 20$ billion to Venezuela at First Latin America-China Forum in Beijing. Venezuela Analysis January 09. Available at: http://venezuelanalysis.com/news/11143

China-Latin America Finance Database. The Dialogue. Available at: www.thedialogue.org/map_list.

Clinton, H., 2011 . America's Pacific Century, Foreign Policy, November 10. Available at: http://foreignpolicy.com/

Jacques, M., 2009. When China Rules the World: The End of the Western World and the Birth of a New Global Order. London: Penguin Books.

Ferguson, N., 2010. Global Business: The History Man. A Historical Perspective on the Global Financial Crisis. BBC. Available at: http://www.bbc. co.uk/iplayer/console/p007qdv5.

Gresh, A., 2008. "Understanding the Beijing Consensus". Le Monde Diplomatique: English Edition. Available at: www.modediplo. com/2008/11/03beijingconsensus.

Lee, B., 2015. What is China's Way?. The Diplomat. February 16. Available at: www.thediplomat.com/2015/02/what-is-chinas-way.

Leonard, A., 2006. No Consensus on the Beijing Consensus. Salon.com. Available at: www.salon.com/2006/09/15/beijing-consensus.

Manriquez, J.L., Alvarez, L.F., 2014. Mao's steps in Monroe's backyard: towards a United States-China hegemonic struggle in Latin America? The Brazilian Journal of International Politics (RBPI)57 (special edition): 9-27.

Passos, P. L., 2015. Um Drible no Mercosul. Jornal Folha de São Paulo, Brazil. January 30. Available at: www1.folha.vol.com.br/colunas/ pedropassos/2015/01/1582689-um-drible-no-mercosul

Ramo, J. C., 2004. The Beijing Consensus. London: Foreign Policy Centre. 
Shixue, J., 2006. Recent Development of Sino-Latin American Relations and its Implications. Estudios Internacionales XXXVIII (152): 12-14.

Schiere, R. and Rugamba, A., 2011. Chinese Infrastructure Investments and African Integration. African Development Bank Group, Working Paper n. 127. Tunis, Tunisia.

Tiezzi, S., 2015. Despite US-Cuba Détente, China Forges ahead in Latin America. The Diplomat, January 9. Available at: www. thediplomat. com/2015/01/despite-us-cuba-detente-china-forges-ahead-inlatin-america/.

Willianson, J., 2004. A Short History of the Washington Consensus. Proceedings from 2004 "From the Washington Consensus towards a New Global Governance". Barcelona, Spain, September 24-25.

Ernani Contipelli is the Director-General and one of the founding members of the Center for European Strategic Research (CESR). Currently, he is a Professor of Political and Constitutional Law at the Faculty of Juridical Sciences of the Universidad Autónoma de Chile and Unochapeco (Brazil). He obtained two post-doctorate degrees in Comparative Politics at the Universidad Complutense de Madrid and Universitat Pompeu Fabra (Spain) and a PhD in Public Law at the Pontificia Universidade Católica de São Paulo (Brazil). He has various experience in the academic field working as Visiting Research and Professor in different countries such as Spain, Italy, France, Brazil, Mexico, Chile, Korea, China and others. He has published 5 books and several articles concerning his research areas of interests: Constitutional and Comparative Public Law, Comparative Politics and Federalism, Digital Democracy, International Development Cooperation: Europe, Asia and Latin America, Emerging Powers and Global Governance, Regional Integration and National Minorities.

Simona Picciau is researcher and project coordinator and one of the founding members of the Center for European 
(2) Strategic Research (CESR). She has obtained a degree in political science with a specialization in international affairs and earned two Masters Degrees - in Relations with China at the University of Turin (2006) and in International Management at the institute Inseec in Paris (2008). She is a PhD Candidate at the University Paris Diderot in France. She lived several years in Paris working as project manager in international agencies in the field of international communication. Her research interests include International Relations, Asian and Latin America affairs, European Regional integration and interregional relations; emerging powers, global governance and European Union's foreign policy. 